\title{
PENGEMBANGAN PRODUK OBAT KUMUR KONSENTRAT DENGAN BAHAN AKTIF MINYAK ATSIRI DAUN SIRIH DAN DAUN CENGKEH
}

\section{PRODUCT DEVELOPMENT OF CONCENTRATED MOUTHWASH WITH BETEL NUT LEAF AND CLOVE LEAF ESSENTIAL OIL AS ACTIVE INGREDIENTS}

\author{
Dwi Setyaningsih", $^{1,2)}$, Siti Rahmi Nuabdi ${ }^{1)}$, dan Neli Muna ${ }^{2)}$ \\ ${ }^{1)}$ Departemen Teknologi Industri Pertanian, Fakultas Teknologi Pertanian, IPB \\ ${ }^{2}$ Pusat Penelitian Surfaktan dan Bioenergi, LPPM, IPB \\ Email : dwisetya.sbrc@gmail.com
}

Makalah: Diterima 3 Juli 2019; Diperbaiki 13 Oktober 2019; Disetujui 30 Oktober 2019

\begin{abstract}
Tooth and mouth disease that is suffered by many people is the reason for the increasing usage of mouthwash. Mouthwash on the market contains alcohol which causes side effects. The purpose of this study is to develop mouthwash concentrate based on essential oil (betel leaves and cloves) that can be accepted by prospective consumers, and to analyze the eligibility criteria of the mouthwash industry investment. The respondents 100 peoples, ranging in 15 to 62 y.o including visitors at Botani Square Mall, Sempur Field, Bhayangkara Hospital Bogor, and IPB students. The research uses an action research approach including market identification, prototype design, research and development, product acceptance analysis and financial analysis. Some problems raised from respondent interview were the side-effects of product, no measuring cup attached, less practical package, and the price was not affordable. The research solution was a practical $30 \mathrm{~mL}$ prototype of bottle drops with measuring cap. The production cost was IDR 6,808 and selling price (based on customer willingness to buy) of IDR 20,000. The result also showed a good acceptance of product by most respondents. Based on financial analysis, this product was concluded as feasible for industrial implementation.
\end{abstract}

Keywords: alcohol mouthwash, betel-clove essensial oils, financial analysis, mouthwash industry

\section{ABSTRAK}

Penyakit gigi dan mulut yang banyak diderita oleh masyarakat menjadi alasan pemakain obat kumur semakin meningkat. Obat kumur beredar di pasaran mengandung alkohol yang memiliki efek samping. Tujuan penelitian ini adalah mengembangkan produk obat kumur konsentrat berbasis minyak atsiri (daun sirih dan cengkeh) yang dapat diterima oleh calon konsumen serta menganalisis kriteria kelayakan investasi industri obat kumur. Responden berjumlah 100 orang, rentang usia 15-62 tahun meliputi pengunjung Botani Square, Lapangan Sempur, RS Bhayangkara Bogor, dan mahasiswa IPB. Penelitian menggunakan pendekatan riset aksi (action research) meliputi identifikasi pasar, desain prototipe, riset dan pengembangan, analisis penerimaan produk serta analisis finansial. Permasalahan yang dihadapi konsumen antara lain efek samping yang ditimbulkan, tidak adanya takaran penggunaan, kemasan kurang praktis, dan harga yang tinggi. Desain prototipe produk berupa kemasan botol tetes $30 \mathrm{~mL}$. Harga pokok produksi sebesar Rp 6.808 dan harga penjualan berdasarkan keinginan responden sebesar Rp 20.000. Hasil riset juga menunjukkan penerimaan yang baik terhadap produk. Analisis finansial menyimpulkan bahwa industri obat kumur ini layak untuk dilaksanakan.

Kata kunci: analisis pasar, obat kumur, minyak atsiri, daun sirih, daun cengkeh

\section{PENDAHULUAN}

Penyakit gigi dan mulut yang banyak diderita oleh masyarakat secara umum adalah penyakit penyangga gigi (radang gusi), karies gigi (gigi berlubang) serta halitosis (bau mulut). Menurut WHO, penderita kerusakan gigi terdiri atas $60-90 \%$ anak usia sekolah dan hampir $100 \%$ orang dewasa. Selain itu, data prevalensi nasional masalah gigi dan mulut adalah 25,9\% (Riset Kesehatan Dasar, 2013). Salah satu cara sederhana membersihkan rongga mulut secara keseluruhan yaitu dengan cara berkumur menggunakan obat kumur. Obat kumur yang disarankan untuk anakanak adalah yang tidak mengandung alcohol (Karimi
2019). Penggunaan produk obat kumur dilakukan secara rutin 1-2 kali sehari setelah sikat gigi (Salsabila, 2016).

Menurut McCullough dan Farah 2008, sebanyak $70 \%$ dari produk obat kumur komersial di pasaran mengandung 5-26\% alkohol. Kandungan alkohol dalam obat kumur dengan konsentrasi tinggi menyebabkan efek oral yang merugikan seperti ulserasi mukosa, radang gusi, nyeri bahkan resiko terkena kanker mulut (Montano, 2018). Penelitian Satpathy et al. (2013) menyimpulkan bahwa obat kumur beralkohol berpengaruh pada timbulnya oral pain (nyeri di mulut) berapapun konsentrasinya, sensasi terbakar (Lemos -Junior CA, Villoria GEM 2008), dan perubahan warna di gigi (Moreira et al., 
2013). Alkohol bersifat mengeringkan, sehingga mengurangi air ludah dan menyebabkan masalah bau nafas (Kumar dan Athiban, 2017). Alkohol juga menyebabkan larutnya polimer yang digunakan untuk restorasi gigi (Moraes et al., 2014) dan menurunnya kekuatan pengikat kawat gigi (Santana et al., 2017). Selain itu, penggunaan Sodium Lauryl Sulphate (SLS) melebihi batas yang dianjurkan dapat menyebabkan terjadinya iritasi pada rongga mulut, ulserasi yang parah (Scully, 2004), penurunan kelarutan saliva serta perubahan sensitivitas rasa (Roslan et al., 2009).

Pola konsumsi masyarakat terhadap produk herbal semakin lama semakin mengalami peningkatan. Menurut Kementrian Perdagangan Republik Indonesia (2014), pertumbuhan ekspor obat herbal Indonesia selama periode 2009-2013 mengalami kenaikan sebesar $6,49 \%$ per tahun. Meskipun menurut Marchetti et al. (2011), penggunaan minyak atsiri pada obat kumur non alkohol memiliki efek penghambatan yang kurang terhadap pembentukan plak dibanding larutan alkohol tradisional. Sebaliknya riset Kulkarni et al (2017) membandingkan efikasi plak antara obat kumur beralkohol yang mengandung minyak atsiri dan obat kumur non alkohol dengan bahan aktif chlorhexidine menunjukkan efektifitas yang sebanding selama 4 hari. Berdasarkan hal tersebut dan melihat meningkatnya peluang pasar akan produk obat kumur herbal atau alami, maka invensi Salsabila (2016) mengenai produk obat kumur alami atau herbal perlu dikomersialisasikan. Komersialisasi produk obat kumur konsentrat perlu dilakukan agar hasil penelitian ini dapat dirasakan manfaatnya oleh masyarakat. Dalam mengkomersialisasikan suatu produk, diperlukan peninjauan produk yang lebih mendalam. Berdasar masalah yang ada, tujuan penelitian ini adalah mengembangkan produk obat kumur konsentrat yang dapat diterima oleh calon konsumen serta menganalisis kriteria kelayakan investasi industri obat kumur. Penelitian ini diharapkan bermanfaat untuk untuk komersialisasi hasil pertanian, informasi mengenai pengembangan produk obat kumur herbal serta gambaran mengenai rencana bisnis obat kumur konsentrat. Ruang lingkup penelitian terdiri dari identifikasi pasar, desain prototipe, riset dan pengembangan, analisis penerimaan produk dan analisis finansial.

\section{METODE PENELITIAN}

Metode penelitian adalah pendekatan riset aksi (action research) yang meliputi :

\section{Identifikasi Pasar}

Identifikasi pasar dilakukan dengan menyebarkan kuesioner kepada 100 responden dan studi literatur. Jumlah 100 responden dipilih untuk mendapatkan hasil yang representatif dengan syarat minimal jumlah responden untuk mewakili populasi dalam statistik adalah 30 responden. Analisis identifikasi pasar dilakukan menggunakan analisis TAM (Total Addressable Market), SAM (Served Available Market), dan TM (Target Market). Pemilihan responden dilakukan dengan cara nonprobabilistic purposive sampling, yaitu pada kelompok usia 15-62 tahun dan merupakan pengguna obat kumur. Kuesioner tergolong semi terbuka, yaitu memberikan pendapat menurut pilihan-pilihan yang telah disediakan dan memberikan kebebasan untuk jawaban lainnya.

\section{Desain Prototipe}

Desain prototipe dilakukan dengan membuat produk, desain kemasan, serta penentuan harga pokok produksi. Desain kemasan dibuat menggunakan Corel Draw X7. Harga pokok produksi ditentukan berdasarkan perhitungan ekonomi sederhana, yaitu hasil penjumlahan biaya pokok produksi meliputi biaya biaya tetap (tenaga kerja, administrasi (ATK, telepon, dokmentasi, FC), pajak, pemeliharaan alat-mesin, dan penyusutan) dan biaya tidak tetap (bahan baku, utilitas, distribusi dan transportasi).

\section{Riset dan Pengembangan}

Riset dan pengembangan dilakukan untuk menjaga dan meningkatkan kualitas produk obat kumur. Metode yang digunakan yaitu studi literatur mengenai karakteristik produk dan formulasi obat kumur konsentrat dari penelitian Salsabila (2016). Pada bagian ini juga dilakukan kajian peningkatan skala menggunakan kesamaan geometris dan analisis dimensional.

\section{Analisis Penerimaan Produk}

Analisis penerimaan produk dilakukan untuk mengetahui respon dari seluruh kegiatan sebelumnya terhadap penerimaan calon pelanggan. Analisis ini dilakukan untuk menguji solusi yang diberikan kepada responden potensial yang telah ditentukan berdasarkan tahapan identifikasi pasar.

\section{Analisis Finansial}

Analisis finansial merupakan perbandingan antara pengeluaran dan pemasukan dari suatu proyek berdasarkan sudut pandang badan usaha atau orang yang menanamkan modal. Kriteria-kriteria yang digunakan untuk melakukan analisis finansial diantaranya Net Present Value (NPV), Internal Rate of Return (IRR), Net Benefit Cost Ratio, Pay Back Period (PBP) dan analisis sensitivitas berupa inflasi $3,82 \%$ per tahun (BPS, 2017) dan penambahan biaya bahan baku utama sebesar 27,34\% per tahun (Pusat Data dan Sistem Informasi Pertanian, 2014).

\section{Waktu dan Tempat Penelitian}

Penelitian dilaksanakan pada bulan Februari 2017-Mei 2017. Penelitian dilaksanakan di Bogor pada beberapa tempat pencarian responden 
diantaranya pengunjung Botani Square, Lapangan Sempur, Rumah Sakit Bhayangkara Bogor, dan mahasiswa Institut Pertanian Bogor.

\section{HASIL DAN PEMBAHASAN}

\section{Identifikasi Pasar}

Ukuran pasar produk obat kumur terdiri dari Total Addressable Market (TAM), Served Available Market (SAM) dan Target Market (TM) (Blank dan Dorf 2012). Ukuran pasar dapat dilihat pada Gambar 1. TAM adalah jumlah peluang suatu konsumen untuk menjadi pasar pada suatu produk atau jasa yang ditawarkan. Menurut Badan Pusat Statistik (2013), jumlah penduduk produktif Indonesia umur 15-64 tahun pada tahun 2017 diproyeksikan sebesar 176,8 juta penduduk. Kamaludin (2016) menyatakan bahwa dalam hitungan BPS jumlah kelompok masyarakat kelas menengah ke atas berjumlah 60\%, sehingga penduduk usia 15-64 tahun yang merupakan masyarakat menengah ke atas diperkirakan sebanyak 106,1 juta penduduk. Dari data wawancara penelitian terlihat bahwa calon konsumen akan menggunakan obat kumur sebanyak 8 kali per minggu. Asumsi 1 botol kemasan $30 \mathrm{~mL}$ akan habis selama 1 bulan dan harga jual obat kumur konsentrat sebesar Rp 20.000 per botol, maka nilai TAM sebesar Rp 2,12 triliun per bulan atau sebesar Rp 25,46 triliun per tahun dengan jumlah penjualan 1,27 milyar botol per tahun.

SAM adalah potensi pasar yang dapat dijangkau oleh perusahaan obat kumur konsentrat. Menurut ACNeilsen Retail Audit (2005) dalam Andayani (2007), pangsa pasar merk-merk obat kumur di 12 kota pada tahun 2005 diantaranya: Listerine (52,3\%), Pepsodent $(17,1 \%)$, Enkasari $(6,2 \%)$, Betadine $(6,3 \%)$, Fresh $(1,5 \%)$, Oral-B $(7,5 \%)$, dan lainnya $(9,1 \%)$. Dengan pertimbangan pangsa pasar produk herbal yang dijadikan kompetitor, saluran yang dipilih adalah toko ritel. Merk obat kumur herbal diantaranya Mustika Ratu, Total Care Herb, Pepsodent Herbal Natural, Colgate Herbal dan Listerine Natural. Diasumsikan kelima merk obat herbal tersebut diatas mempunyai nilai sama dengan obat kumur konsentrat produk penelitian, maka potensi pasar produk obat kumur herbal menjadi 1,52\% (pangsa pasar 9,1\% dibagi 6 jenis produk herbal) dari nilai TAM total. SAM produk obat kumur konsentrat sebesar $1,52 \%$ atau setara dengan 1,6 juta penduduk. SAM obat kumur konsentrat yang dapat dijangkau sebanyak 19,35 juta botol per tahun dengan pendapatan sebesar Rp 387 milyar per tahun.

TM adalah sasaran pasar yang benar-benar menggunakan produk perusahaan. Target pasar yang dituju mencakup kota dan kabupaten Bogor sebesar 2,54\% dari total penduduk Indonesia (Pusat Data dan Analisa Pembangunan Jawa Barat 2015). Potensi pasar obat kumur pada target pasar sebanyak 40.963 pelanggan. Berdasarkan hasil analisis ukuran pasar, potensi pasar obat kumur pada target market sebanyak 491.557 botol per tahun dengan pendapatan sebesar Rp 9,8 milyar per tahun.

\section{Pengujian Masalah}

Sebagian besar responden saat ini banyak yang belum mengetahui efek samping maupun hukum menggunakan obat kumur beralkohol, hal ini dibuktikan dengan sebagian besar responden yang masih menggunakan obat kumur alkohol. Menurut drg. Emma, salah satu dokter gigi di RS Bhayangkara Bogor, beliau tidak menyarankan pasiennya menggunakan obat kumur kecuali untuk kasus tertentu seperti bau mulut. Beliau tidak menyarankan karena obat kumur banyak mengandung bahan kimia yang memiliki efek samping terutama alkohol yang beresiko menyebabkan kanker. Sesuai dengan Wirth et al. (2012), obat kumur beralkohol dapat menjadi cairan yang agresif merusak jaringan rongga mulut dan menyebabkan detasemen epitel, ulserasi mukosa, gingivitis, petechias dan lesi putih pada penggunaan jangka panjang. Dari segi kehalalan, 96\% responden setuju bahwa kehalalan produk merupakan hal yang penting dan sebanyak $87 \%$ menjadikan kehalalan produk merupakan atribut yang dipertimbangkan dalam memilih suatu produk.

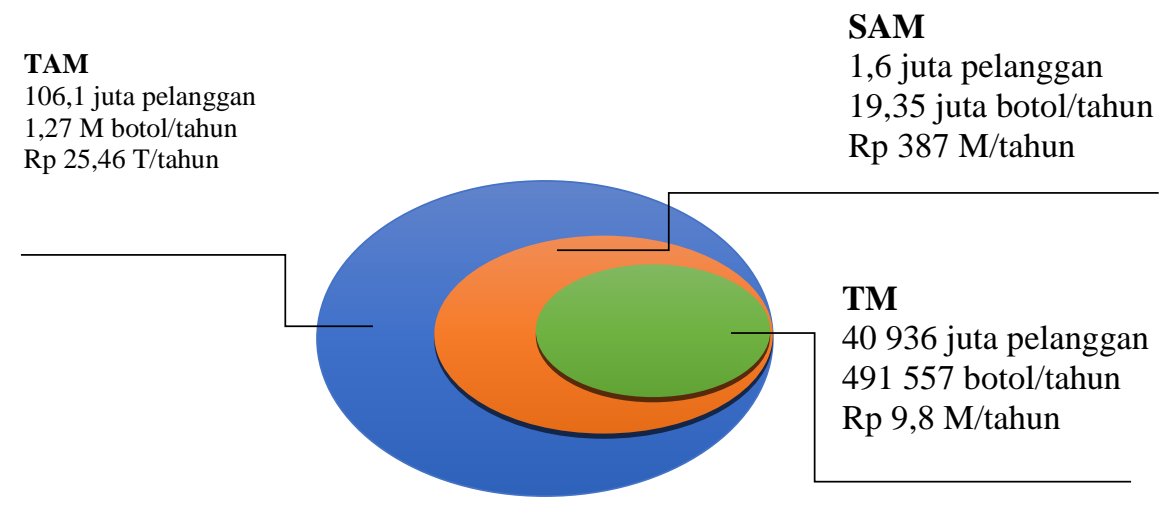

Gambar 1. Ukuran pasar produk obat kumur konsentrat 
Berdasarkan hasil survey terhadap responden diketahui obat kumur yang digunakan responden sebagian besar memiliki beberapa permasalahan, dapat dilihat pada Gambar 2. Sebanyak $40 \%$ responden memiliki permasalahan pada efek samping yang ditimbulkan, 37\% tidak adanya takaran pemakaian, $13 \%$ mengatakan kemasan kurang praktis, $2 \%$ harga yang tinggi, dan $8 \%$ lainnya tidak memiliki masalah. Berdasarkan masalah-masalah yang ada, diketahui masalah utama yang dihadapi responden yaitu efek samping yang ditimbulkan. Efek samping yang dimaksud dapat dilihat pada Gambar 3.

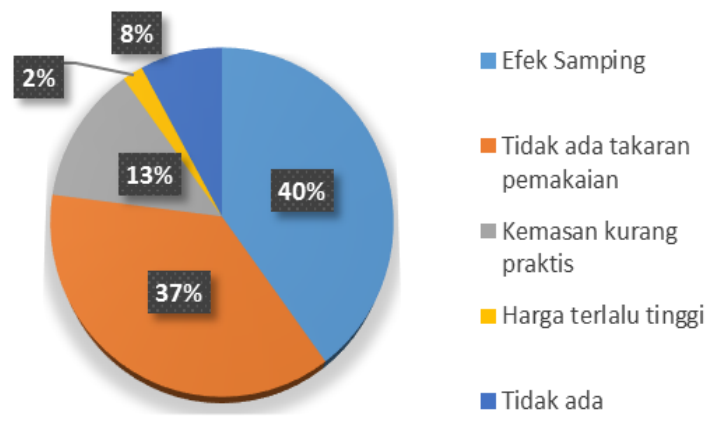

Gambar 2. Diagram persentase masalah responden terhadap obat kumur

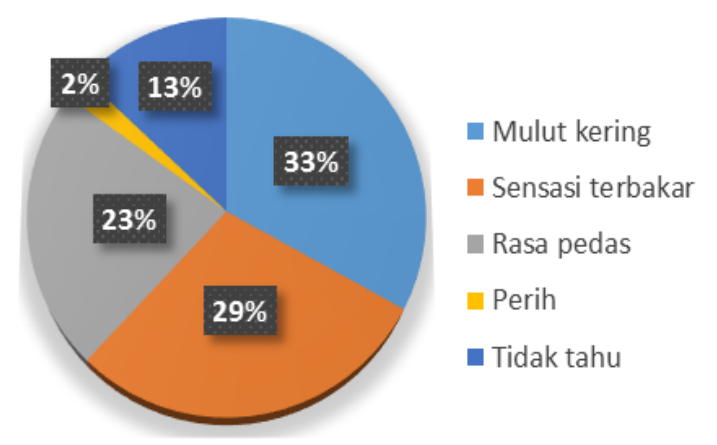

Gambar 3. Diagram persentase responden mengenai masalah efek samping obat kumur

Sebanyak $33 \%$ responden menyatakan obat kumur alkohol menimbulkan mulut kering, 29\% menyatakan sensasi terbakar, $23 \%$ menyatakan rasa pedas, $2 \%$ menyatakan perih di mulut, dan $13 \%$ lainnya tidak merasakan permasalahan ini.

\section{Desain Prototipe}

Obat kumur dibuat dalam bentuk sediaan konsentrat karena keinginan konsumen untuk menghemat volume. Konsentrat merupakan sediaan berbentuk pekatan dengan konsentrasi bahan aktif yang cukup tinggi. Bentuk sediaan konsentrat selain dapat menghemat volume juga dapat menghemat tempat penyimpanan karena kemasan menjadi lebih kecil sehingga mudah untuk dibawa berpergian dibandingkan dengan obat kumur bentuk cair.
Formulasi obat kumur konsentrat dibuat berdasarkan hasil penelitian Salsabila (2016) yang dimodifikasi yaitu formulasi obat kumur konsentrat dengan bahan aktif minyak atsiri sirih dan cengkeh. Minyak atsiri sirih dan cengkeh dipilih sebagai bahan aktif pengganti alkohol karena minyak sirih memiliki aktivitas anti bakteri terhadap Streptococcus mutans pada dengan konsentrasi $0,1 \%$ (Yendriwati dan Henny, 2008), efek antibakteri terhadap E. faecalis pada konsentrasi 20\% (Harman, 2013). Menurut Raut dan Karupayil (2014), minyak cengkeh memiliki aktivitas antibakteri terhadap $E$. coli pada konsentrasi $0,025 \%, S$. aureus pada konsentrasi $\leq 0,05 \%$ serta menghambat pertumbuhan jamur penyebab penyakit sariawan Candida albicans. Penambahan minyak jahe bertujuan untuk menghilangkan aftertaste yang tidak diinginkan dari rasa pahit dari minyak sirih (Salsabila, 2016).

Daya tarik utama desain kemasan berupa warna, struktur fisik atau bentuk, simbol dan angka serta tipografi (Klimchuk dan Krasovec, 2007). Warna kemasan merupakan fitur visual yang paling pertama diidentifikasi oleh konsumen. Warna kemasan yang digunakan pada obat kumur adalah kombinasi dari hijau, biru, dan transparan atau tembus pandang. Warna hijau melambangkan kealamian dan kesegaran dari produk yang ditawarkan serta menandakan produk bermanfaat bagi kesehatan. Warna biru dengan percikan zat cair melambangkan kesegaran sesuai dengan sensasi segar yang ditimbulkan setelah penggunaan produk. Warna transparan atau tembus pandang dapat memudahkan responden untuk menilai kualitas produk secara fisik.

Konten label kemasan produk yang ditawarkan diantaranya merk, komposisi, kegunaan produk, cara pemakaian, cara penyimpanan, dan berat bersih kemasan. Kemasan botol $30 \mathrm{~mL}$ dipilih berdasarkan kebiasaan responden sebanyak $62 \%$ menggunakan kemasan ukuran sedang $250 \mathrm{~mL}$ yang apabila dikonversi dengan penambahan air 1:10 kemasan $30 \mathrm{~mL}$ akan mendekati $250 \mathrm{~mL}$. Kemasan dilengkapi dengan cup measuring untuk mengukur volume obat kumur konsentrat dan air yang digunakan. Sebanyak $37 \%$ responden atau permasalahan responden terbesar yang mereka hadapi saat ini pada penggunaan obat kumur adalah tidak adanya takaran penggunaan. Label kemasan dapat dilihat pada Gambar 4.

Simbol yang digunakan produk adalah huruf $\mathrm{H}$ dalam kurung dengan warna hijau. Huruf $\mathrm{H}$ berasal dari kata herbal yang menggambarkan produk tersebut menonjolkan sisi herbal atau kealamian dari produknya. Gambar mulut dengan sensasi segar yang digunakan dapat mengkomunikasikan penggunaan produk kepada konsumen. Merk produk ditentukan berdasarkan eliminasi beberapa pilihan merk yang sebelumnya ditentukan. Merk produk yang dipilih adalah 
"FresHai". Prototipe kemasan dapat dilihat pada Gambar 5.

Penentuan harga pokok produksi ditentukan dengan perhitungan hasil penjumlahan biaya tetap dan biaya tidak tetap. Harga pokok produksi prototipe obat kumur konsentrat volume $30 \mathrm{~mL}$ adalah Rp 6.808. Harga penjualan yang ditetapkan berdasarkan perhitungan tersebut adalah Rp 20.000 per kemasan botol $30 \mathrm{~mL}$. Untuk lebih jelasnya akan dibahas pada bagian analisis financial.

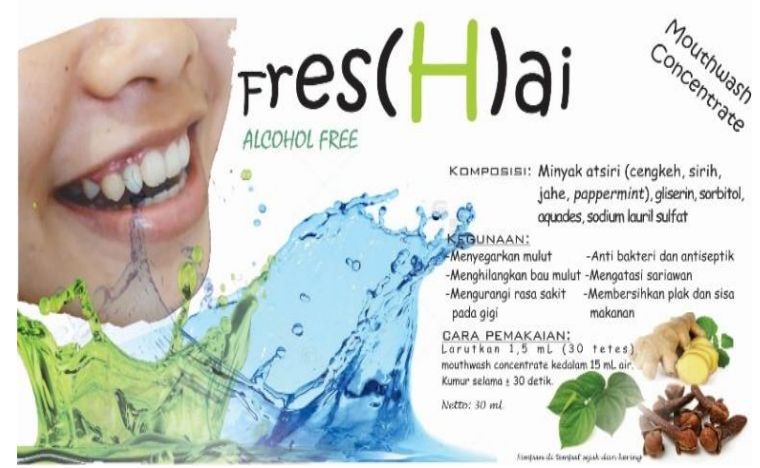

Gambar 4. Label kemasan produk

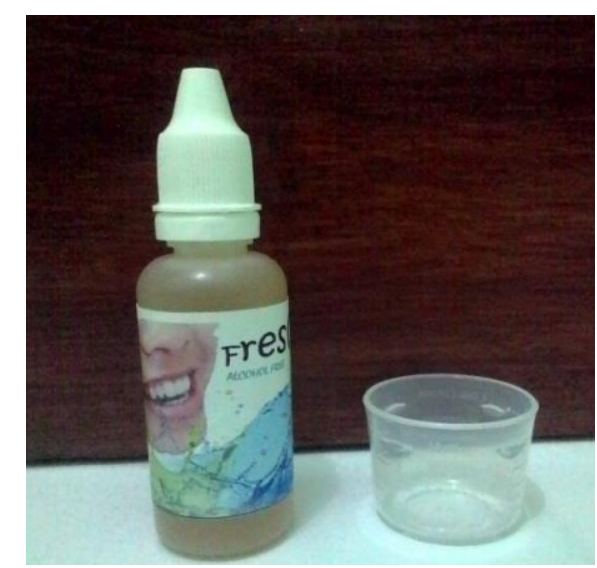

Gambar 5. Prototipe produk obat kumur konsentrat

\section{Riset dan Pengembangan}

Produk obat kumur yang ditawarkan memiliki $\mathrm{pH} 5,99$ dalam bentuk konsentrat dan $\mathrm{pH}$ 6,24 dalam pengenceran 1:10. Angka tersebut menunjukkan bahwa produk tersebut aman untuk digunakan berkumur karena rentang $\mathrm{pH}$ yang dapat diterima mulut adalah 3-8. Viskositas obat kumur dalam bentuk konsentrat sebesar 129,98 cP dan viskositas obat kumur dengan pengenceran 1:10 sebesar 1,17 cP. Viskositas yang tinggi menunjukkan tingginya konsentrasi dalam obat kumur konsentrat sehingga dalam penggunaannya perlu dicampurkan dengan air. Viskositas obat kumur pengenceran 1:10 memiliki viskositas mendekati nilai viskositas air sehingga obat kumur tersebut nyaman dan mudah dalam penggunaannya. Obat kumur konsentrat memliki warna kuning bening. Obat kumur memiliki indeks daya hambat antimikroba sebesar 1 terhadap $S$. aureus dan 0,9 terhadap E. coli. Angka indeks daya hambat tersebut menunjukkan daya hambat obat kumur berkategori sedang (Salsabila, 2016).

Menurut McCabe et al. (1985) perancangan alat dilakukan dengan pengkajian peningkatan skala laboratorium menjadi skala yang lebih besar. Peningkatan skala proses pencampuran bertujuan untuk mendesain agitator untuk mencapai hasil yang sama dalam skala besar yang menggambarkan hasil pada skala laboratorium. Peningkatan skala menggunakan kesamaan geometris dan analisis dimensional. Kesamaan geometris disesuaikan dengan rasio yang tetap antara standar reaktor dan reaktor skala yang diinginkan. Analisis dimensional digunakan untuk menentukan kecepatan impeller yang dibutuhkan. Kecepatan impeller digunakan untuk menaksir kebutuhan daya yang diperlukan untuk memutar impeller (McCabe et al., 1985)

Tabel 1. Spesifikasi bejana dengan volume kerja $100 \mathrm{~mL}$

\begin{tabular}{lcc}
\hline Parameter & Satuan & Nilai \\
\hline Volume kerja (V) & $\mathrm{mL}$ & 100 \\
Tinggi Tangki $(\mathrm{Ht})$ & $\mathrm{cm}$ & 6.5 \\
Diameter Impeller $(\mathrm{Di})$ & $\mathrm{cm}$ & 3 \\
Diameter Tangki $(\mathrm{Dt})$ & $\mathrm{cm}$ & 5 \\
Tinggi Cairan $(\mathrm{Zi})$ & $\mathrm{cm}$ & 5 \\
\hline
\end{tabular}

Spesifikasi bejana skala laboratorium dapat dilihat pada Tabel 1. Pada peningkatan skala, ditetapkan impeller pitch blade turbin dengan 4 blade. Menurut McCabe et al. (1985), impeller jenis ini menghasilkan pola aliran radial dan aksial sehingga akan menghasilkan pola aliran turbulen. Impeller jenis ini juga biasa digunakan untuk zat cair berviskositas rendah. Umumnya, pitch blade turbin yang digunakan memiliki kemiringan $45^{\circ}$ (Moss dan Basic, 2013). Perhitungan skala proses pencampuran pada skala 120 L berdasarkan kesamaan geometri meliputi jenis impeller, perbandingan diameter tangki (Dt) dan diameter impeller (Di). Hasil perhitungan kesamaan geometri untuk skala $120 \mathrm{~L}$ dapat dilihat pada Tabel 2 dan skema tangki dapat dilihat pada Gambar 6. Berdasarkan hasil perhitungan analisis dimensional, kecepatan impeller yang diperlukan untuk menggerakan impeller skala $120 \mathrm{~L}$ adalah 76,22 rpm dan daya yang dibutuhkan sebesar 0,44 hp atau setara dengan 332,67 Watt. Kebutuhan daya dihitung dengan mengalikan faktor koreksi sebesar 0,58

\section{Analisis Penerimaan Produk}

Hasil analisis kesesuaian produk dengan permasalahan dapat dilihat pada Gambar 7. Hasil pengujian penerimaan produk menunjukkan bahwa prototipe produk yang ditawarkan dapat diterima dengan baik oleh responden. Berdasarkan hasil uji penerimaan produk menunjukkan $87 \%$ responden akan membeli produk obat kumur yang ditawarkan. Untuk permasalahan utama yang dihadapi responden berupa efek samping yang ditimbulkan pada obat 
kumur beralkohol, sebanyak $100 \%$ responden setuju bahwa produk memiliki efek samping berupa mulut kering, rasa pedas, serta sensasi terbakar lebih sedikit dibanding obat kumur beralkohol. Responden meyakini bahan tradisional atau herbal lebih dipercaya aman secara turun menurun.

Tabel 2. Spesifikasi reaktor pada skala $120 \mathrm{~L}$

\begin{tabular}{lcc}
\hline Parameter & Satuan & Nilai \\
\hline Volume kerja $(\mathrm{V})$ & $\mathrm{L}$ & 120 \\
Tinggi tangki $(\mathrm{Ht})$ & $\mathrm{cm}$ & 69,56 \\
Diameter impeller $(\mathrm{Di})$ & $\mathrm{cm}$ & 17,82 \\
Diameter tangki $(\mathrm{Dt})$ & $\mathrm{cm}$ & 53,45 \\
Tinggi cairan $(\mathrm{Hi})$ & $\mathrm{cm}$ & 53,45 \\
Tinggi impeller dari & $\mathrm{cm}$ & 17,82 \\
bawah tangki $(\mathrm{E})$ & & \\
Lebar impeller $(\mathrm{W})$ & $\mathrm{cm}$ & 3,56 \\
Panjang impeller $(\mathrm{L})$ & $\mathrm{cm}$ & 4,45 \\
Lebar baffle $(\mathrm{J})$ & $\mathrm{cm}$ & 4,45 \\
Densitas obat kumur $(\rho)$ & $\mathrm{g} / \mathrm{m}^{3}$ & 1,35 \\
Viskositas obat kumur $(\mu)$ & $\mathrm{g} / \mathrm{m} . \mathrm{s}$ & 1,30 \\
Kecepatan impeller $(\mathrm{N})$ & $\mathrm{rpm}$ & 76,22 \\
Daya $(\mathrm{P})$ & $\mathrm{hp}$ & 0,44 \\
\hline
\end{tabular}

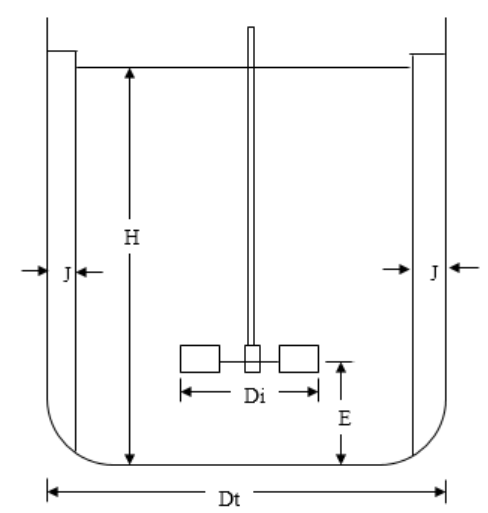

Gambar 6. Skema tangki berpengaduk

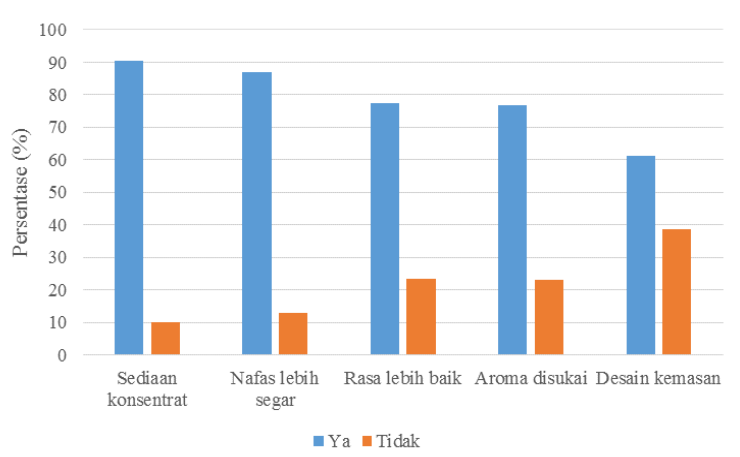

Gambar 7. Grafik kesesuaian produk dengan permasalahan

Sebanyak $97 \%$ responden menyatakan produk tidak membuat mulut kering, 94\% responden menyatakan produk tidak menimbulkan sensasi terbakar, dan $77 \%$ responden menyatakan produk memiliki rasa yang lebih disukai dari produk yang biasa responden gunakan. Pada pengujian ini, terdapat sebagian kecil responden yang ragu-ragu terhadap efek yang ditimbulkan setelah pemakaian dikarenakan jika terlalu lama berkumur, sensasi terbakar terasa namun tidak sekeras obat kumur alkohol. Beberapa responden merasakan pahit di awal berkumur, namun lama-kelamaan rasa pahit hilang lalu terasa enak.

Pada permasalahan tidak ada takaran pemakaian, sebanyak $71 \%$ responden setuju bahwa produk tersebut memiliki takaran yang pas. Sedangkan $29 \%$ responden lainnya masih ragu-ragu. Keragu-raguan ini disebabkan karena volume yang ditetapkan terlalu banyak. Selain itu, belum diterapkannya Cara Pembuatan Obat Tradisional yang Baik (CPOTB) sehingga responden merasa ragu mengenai takaran yang digunakan. CPOTB sendiri mengatur tentang dokumen produksi sebagai standar bagi setiap produk, memuat juga komposisi untuk setiap satuan takaran.

Permasalahan kemasan kurang praktis disebabkan karena ketidakpraktisan dalam penggunaan maupun kemudahan saat dibawa. Sebanyak $68 \%$ responden mengatakan bahwa mereka menyukai kemasan tetes yang ditawarkan. Menurut mereka kemasan tetes dapat mengontrol volume yang keluar sehingga tidak khawatir berlebih. Namun terdapat $32 \%$ responden yang mengatakan ragu-ragu terhadap kepraktisan kemasan tetes karena membutuhkan waktu untuk membuat cairan obat kumur. Dalam hal kemudahan saat dibawa, sebanyak $90 \%$ responden menyatakan sediaan konsentrat lebih menarik karena dapat menghemat volume baik volume penggunaan maupun ukuran kemasan. Ukuran kemasan yang kecil menjadikan produk mudah digenggam dan dibawa kemana-mana. Responden yang menyatakan setuju merupakan responden yang lebih menyukai penghematan. Terdapat $10 \%$ responden yang kurang menarik dengan bentuk sediaan konsentrat. Responden yang ragu-ragu tersebut merupakan responden yang memilih kepraktisan dibanding penghematan karena menurut mereka hal tersebut kurang praktis.

Pada permasalahan harga yang tinggi, hanya $2 \%$ responden yang mengatakan harga menjadi permasalahan dalam penggunaan obat kumur. Produk obat kumur konsentrat menawarkan harga yang lebih terjangkau dibandingkan obat kumur yang ada di pasaran. Harga Rp 20.000 merupakan harga terbanyak yang dipilih responden untuk membeli obat kumur. Selain itu, bahan aktif yang digunakan juga merupakan bahan alami sehingga memiliki efek samping lebih lemah.

Penilaian responden terhadap atribut produk yang ditawarkan berdasarkan bentuk sediaan, after taste, rasa, aroma dan kemasan. Sebanyak $90 \%$ responden menyukai bentuk konsentrat pada obat kumur. Sebanyak $87 \%$ responden mengatakan produk membuat nafas lebih segar. Hal ini sesuai dengan tujuan sebagian besar responden 
menggunakan obat kumur untuk membuat nafas lebih segar. Sebanyak $77 \%$ responden menyukai rasa produk serta aroma produk. Beberapa responden yang tidak menyukai rasa dan aroma disebabkan karena tidak menyukai aroma minyak sirih maupun cengkeh. Sebanyak $61 \%$ responden menyukai desain kemasan produk. Secara keseluruhan, semua atribut sudah sesuai dengan keinginan konsumen. Kelima atribut produk menunjukkan jumlah persentase di atas $50 \%$. Namun desain kemasan memiliki tingkat kesukaan paling rendah, hal ini disebabkan warna pada label kemasan yang terlalu lembut sehingga perlu dipilih warna yang lebih cerah untuk menarik perhatian responden. Penilaian terhadap produk dapat dilihat pada Gambar 8.

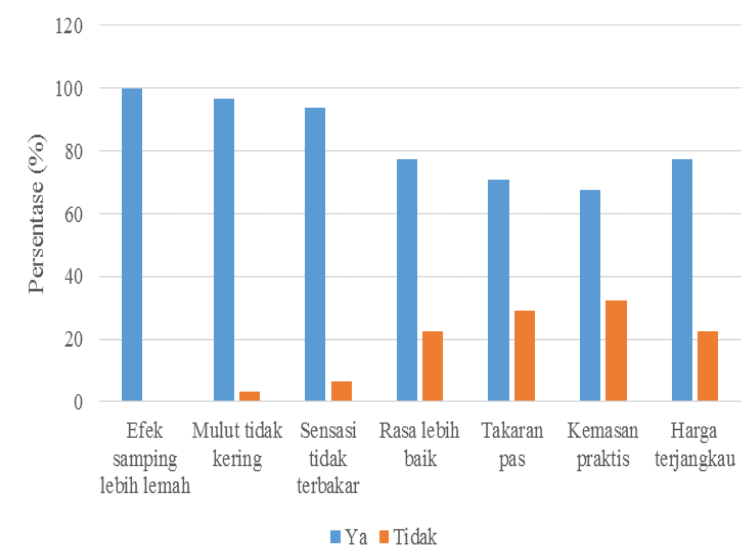

Gambar 8. Grafik penilaian terhadap atribut produk

Konsumsi produk atau jasa oleh pengguna akhir disalurkan melewati perantara yang melaksanakan beragam fungsi disebut saluran pemasaran (Kotler dan Keller 2008). Saluran penjualan yang paling diminati oleh calon konsumen sebanyak $73 \% \%$ melalui toko ritel. Toko ritel yang menjadi pilihan calon konsumen adalah supermarket, minimarket, toko herbal, toko obat dan apotek. Toko ritel dipilih karena kemudahan dalam pembelian produk. Saluran penjualan lain yang diminati calon konsumen yaitu penjulan langsung melalui media daring maupun expo atau bazar yang bertemakan produk herbal. Penjulan melalui daring dipilih karena menurut hasil survey belanja Online MasterCard (2012), sebanyak 77\% responden Indonesia berkecenderungan melakukan belanja daring. Pertumbuhan belanja daring di Indonesia meningkat sebesar $15 \%$. Penjualan melalui expo maupun daring juga berfungsi untuk media promosi produk baru.

Penentuan harga produk ditetapkan berdasarkan harga pilihan respoden terbanyak. Responden menentukan harga produk dibandingkan dengan harga jual produk pesaing di pasaran. Sebanyak 23\% responden akan membeli produk dengan harga > Rp 30.000. Harga Rp 20.000 - Rp 30.000 dipilih sebanyak $64 \%$ responden dan sebanyak $22 \%$ responden memilih harga < Rp
20.000 untuk membeli produk tersebut. Harga yang dipilih dengan preferensi terbanyak adalah Rp 20.000 - Rp 30.000 sebesar 64\%. Jumlah responden yang memilih angka < Rp 20.000 lebih banyak dibandingkan > Rp 30.000 sehingga harga yang ditentukan untuk produk obat kumur kemasan 30 mL adalah Rp 20.000.

\section{Analisis Finansial}

Aspek finansial digunakan untuk menentukan rencana investasi dengan melakukan perhitungan biaya (cost) dan manfaat (benefit) yang diinginkan. Rencana investasi juga dilakukan dengan membandingkan biaya yang dikeluarkan dan pendapatan yang diterima. Analisis finansial dilakukan dengan mempertimbangkan beberapa parameter yang digunakan sebagai tolak ukur diantaranya kapasitas produksi, pangsa pasar, teknologi yang sesuai, pilihan peralatan, jumlah tenaga kerja, fasilitas pendukung, dan proyeksi harga-harga.

Asumsi-asumsi yang digunakan untuk menentukan perkiraan biaya diantaranya:

1. Umur ekonomis proyek direncanakan selama 5 tahun dengan jumlah hari kerja sebanyak 300 hari, asumsi kerja per bulan 25 hari dan jumlah bulan per tahun 12 bulan. Umur proyek ditentukan berdasarkan umur mesin yang digunakan yaitu 5 tahun.

2. Penyusutan menggunakan Straight Line Method

3. Modal terdiri dari investasi dan modal kerja dengan modal kerja ditetapkan selama sebulan pertama produksi.

4. Kapasitas produksi per hari sebanyak 3840 botol, apabila dikonversi per bulan maka kapasitas per bulan 96000 botol dan 1152000 botol per tahun. Masing-masing $30 \mathrm{~mL}$ tiap botol.

5. Target produksi pada tahun pertama sebesar $87 \%$, tahun kedua $90 \%$ serta tahun ketiga dan seterusnya sebesar $100 \%$.

6. Harga listrik per kwh sebesar Rp 1112

7. Harga-harga yang digunakan berdasarkan harga yang digunakan dalam analisis finansial tahun 2017 dan dipengaruhi discount factor dari bank sebesar $12 \%$.

8. Harga bahan baku diasumsikan sama tiap tahun selama 5 tahun periode.

9. Besarnya pajak ditetapkan sebagai berikut:

- Pajak penghasilan badan usaha dihitung berdasarkan Undang-Undang No. 7 tahun 1983 tentang Pajak Penghasilan sebesar 0.25 - (0.6 Miliar/Gross Income) dikali Penghasilan Kena Pajak

- Pajak kendaraan $0.5 \%$ dari harga beli berdasarkan UU no 22 tahun 1999

- Pajak Penambahan Nilai sebesar 10\%

- Pajak Bumi dan Bangunan berdasarkan Undang-Undang no 12 tahun 1985

10. Biaya kontingensi $10 \%$ dari total investasi 


\section{Biaya Investasi}

Biaya investasi terdiri atas biaya investasi dan modal kerja. Biaya investasi tetap terdiri dari biaya pra investasi, mesin dan peralatan, tanah dan bangunan, fasilitas penunjang serta peralatan kantor. Biaya modal kerja adalah biaya yang digunakan saat pertama kali pabrik produksi obat kumur. Biaya modal kerja ditetapkan sebagai biaya operasional untuk satu bulan pertama. Biaya investasi yang diperlukan untuk mendirikan industri obat kumur konsentrat adalah sebagai berikut:

\section{Biaya Pra Investasi}

Biaya pra investasi terdiri dari biaya perizinan tempat usaha, biaya survey, studi kelayakan, UKL, UPL, amdal serta izin pendirian bangunan. Total biaya pra investasi sebesar Rp 80.750.000. Rincian biaya pra investasi dapat dilihat pada Tabel 5.

Tabel 1. Biaya pra investasi

\begin{tabular}{clr}
\hline No & \multicolumn{1}{c}{$\begin{array}{c}\text { Jenis Biaya Pra } \\
\text { Investasi }\end{array}$} & Biaya (Rp) \\
\hline 1 & Perizinan Tempat Usaha & 12.000 .000 \\
2 & Biaya Survey & 10.000 .000 \\
3 & Studi Kelayakan & 30.000 .000 \\
4 & UKL, UPL, Amdal & 25.000 .000 \\
5 & IMB & 3.750 .000 \\
\hline \multicolumn{2}{l}{ Total Biaya Pra Investasi } & 80.750 .000 \\
\hline
\end{tabular}

\section{Biaya Pengadaan Tanah dan Bangunan}

Biaya pengadaan tanah yaitu sebesar Rp 180.000.000 dengan asumsi lahan yang dibutuhkan yaitu sebesar $150 \mathrm{~m}^{2}$ dan harga tanah per meter persegi yaitu sebesar Rp 1.200.000. Harga bangunan diasumsikan $\mathrm{Rp} 3.750 .000$ per meter persegi, sehingga total harga bangunan sebesar Rp 375.000. 000 .

\section{Biaya Mesin, Peralatan dan Alat Operasional}

Biaya mesin dan peralatan disesuaikan dengan kapasitas produksi obat kumur konsentrat, yaitu sebesar 1.152.000 botol per hari atau 96.000 botol per bulan dan setara dengan 3.840 botol per bulan. Kapasitas minimal mesin dan peralatan adalah 115,2 L per hari. Biaya investasi untuk pengadaan mesin dan peralatan sebesar Rp 287.700.000. Biaya perawatan mesin dan peralatan diasumsikan sebesar $10 \%$ dari total biaya pengadaan. Biaya investasi untuk pengadaan peralatan kantor sebesar Rp 204.050.000.

\section{Biaya Bahan Baku}

Biaya bahan baku terdiri atas gliserin, sorbitol, minyak sirih, minyak cengkeh, minyak peppermint, SLS (Sodium Lauryl Sulfat), aquades, cup measuring dan kemasan. Dalam total kapasitas $100 \%$, total biaya bahan baku sebesar Rp 6.498.067.277 per tahun.

\section{Biaya Kelistrikan}

Biaya penggunaan listrik dipengaruhi oleh jenis alat produksi yang digunakan. Total kebutuhan daya per hari sebesar $23.93 \mathrm{kWh}$. Tarif listrik ditetapkan sebesar Rp 1.112 berdasarkan ketetapan Perusahaan Listrik Negara (PLN). Total biaya listrik per hari untuk operasional pabrik sebesar Rp 26.611 sehingga total biaya listrik per tahun sebesar Rp 7.983.275.

\section{Biaya Tenaga Kerja}

Biaya tenaga kerja terdiri dari tenaga kerja langsung dan tenaga kerja tidak langsung. Tenaga kerja langsung terdiri dari 10 orang karyawan dengan gaji masing-masing tiap bulan sebesar Rp 3.300.000. Biaya yang dibutuhkan untuk menggaji tenaga kerja tidak langsung sebesar Rp 55.000.000 per bulan. Total biaya yang dibutuhkan untuk menggaji tenaga kerja selama satu tahun sebesar Rp 1.056.000.000.

\section{Biaya Penyusutan}

Barang yang mengalami biaya penyusutan diantaranya biaya pra investasi, mesin dan peralatan, tanah dan bangunan serta alat operasional dan kantor. Biaya penyusutan pada industri obat kumur konsentrat sebesar Rp 152.832.000.

\section{Biaya Operasional dan Penerimaan}

Biaya operasional terdiri dari biaya tetap dan biaya tidak tetap. Biaya operasional yang diperlukan untuk memproduksi obat kumur konsentrat selama satu tahun pertama sebesar Rp 6.997.411.080 dengan total penerimaan sebesar Rp 20.044.800.000 dan meningkat sampai tahun ketiga. Biaya operasional tahun pertama dan kedua diasumsikan sebesar $87 \%$ dan $90 \%$ lalu mulai stabil pada tahun ketiga. Biaya operasional pada tahun kedua sebesar $\mathrm{Rp}$ 7.192.592.596 dengan total penerimaan $\mathrm{Rp}$ 20.736.000.000. Pada tahun ketiga dan seterusnya produksi mulai stabil atau $100 \%$ sehingga mengeluarkan biaya operasional sebesar Rp 7.843.197.652 dengan total penerimaan $\mathrm{Rp}$ 23.040.000.000.

\section{Harga Pokok Produksi}

Harga pokok produksi terdiri dari biaya tetap dan biaya tidak tetap. Biaya untuk memproduksi obat kumur konsentrat per botol ukuran $30 \mathrm{~mL}$ sebesar Rp 6.808. Harga jual yang ditetapkan sebesar Rp 20.000 per botol.

\section{Proyeksi Laba Rugi}

Laba yang dihasilkan pada tahun pertama dengan tingkat produksi $87 \%$ sebesar Rp 8.171.624 120 dan semakin meningkat pada tahun kedua dan ketiga sebesar $\mathrm{Rp}$ 8.475.836.554 dan $\mathrm{Rp}$ 9.489.351.822. Laba bersih berasal dari laba operasi yang dikurangi pembayaran pajak. 


\section{Proyeksi Arus Kas}

Arus kas terdiri dari arus kas masuk dan kas keluar. Arus kas masuk terdiri dari laba bersih, modal dan nilai sisa investasi sedangkan kas keluar terdiri dari investasi, modal kerja, dan biaya operasional. Arus kas bersih berasal dari total kas masuk dikurang kas keluar.

Penilaian kriteria kelayakan yang digunakan dalam analisis finansial ini antara lain Net Present Value (NPV), Internal Rate Return (IRR), Benefit Cost Ratio (Net B/C), dan Pay Back Period (PBP). Perhitungan kelayakan proyek menggunakan faktor diskonto sebagai faktor perubahan uang terhadap waktu. Faktor diskonto berperan untuk menggambarkan nilai biaya pada masa sekarang dan menurunkan nilai di masa yang akan datang. Faktor diskonto yang digunakan dalam analisis ini diasumsikan sebesar $12 \%$. Hasil analisis finansial terdapat pada Tabel 6 .

Tabel 6. Hasil analisis finansial

\begin{tabular}{lllll}
\hline NPV (Rp) & IRR (\%) & $\begin{array}{l}\text { Net } \\
\text { B/C }\end{array}$ & PBP (tahun) \\
\hline 3.598 .995 .4 & 136,7949639 & 2,97 & $\begin{array}{l}1,78 \\
\begin{array}{l}1 \text { tahun } \\
\text { bulan })\end{array}\end{array}$ \\
\hline 23,38 & & & 10 \\
\hline
\end{tabular}

\section{Analisis Sensitivitas}

Analisis sensitivitas bertujuan untuk mengetahui perubahan yang terjadi apabila terdapat perubahan parameter produksi. Parameter yang berpengaruh dapat berasal dari penerimaan maupun pengeluaran. Parameter yang diuji pada analisis ini adalah kenaikan harga variabel dan penurunan pendapatan karena kedua hal ini bersifat fluktuatif terhadap waktu. Analisis ini dilakukan pada empat kriteria, yakni NPV, IRR, Net B/C, dan PBP.

Tabel 7. Hasil analisis sensitivitas

\begin{tabular}{lcccc}
\hline \multirow{2}{*}{ Perubahan } & \multicolumn{4}{c}{ Kriteria Investasi } \\
\cline { 2 - 5 } & NPV (Rp) & $\begin{array}{c}\text { IRR } \\
(\%)\end{array}$ & $\begin{array}{c}\text { Net } \\
\text { B/C }\end{array}$ & $\begin{array}{c}\text { PBP } \\
\text { (tahun) }\end{array}$ \\
\hline $\begin{array}{l}\text { Penambahan } \\
\text { biaya } \\
\text { variabel }\end{array}$ & 2.397 .569 .832 & 119 & 2,31 & 2,34 \\
$\begin{array}{l}27,34 \% \\
\begin{array}{l}\text { Penurunan } \\
\text { pendapatan }\end{array}\end{array}$ & 2.033 .723 .983 & 111 & 2,10 & 2,42 \\
$3,82 \%$ & & & & \\
\hline
\end{tabular}

Tabel 7 menunjukkan bahwa perubahan biaya variabel dan total pendapatan mempengaruhi kelayakan usaha obat kumur konsentrat. Menurut Pusat Data dan Sistem Informasi Pertanian (2014), rata-rata harga cengkeh mengalami peningkatan sebesar $27,34 \%$ per tahun. Penambahan biaya variabel sebesar $27,34 \%$ menunjukkan industri obat kumur masih layak untuk dijalankan. Pada saat terjadi penurunan pendapatan sebesar $3,82 \%$ akibat inflasi, industri obat kumur juga masih dikatakan layak untuk dijalankan. Hal ini dilihat dari nilai NPV yang positif, nilai IRR lebih besar dari bunga bank, net $\mathrm{B} / \mathrm{C}$ lebih dari 1 , dan PBP kurang dari masa proyek.

\section{KESIMPULAN DAN SARAN}

\section{Kesimpulan}

Produk obat kumur konsentrat dapat diterima konsumen berdasarkan atribut produk serta dapat mengatasi permasalahan-permasalahan pada konsumen. Permasalahan-permasalahan yang dialami oleh konsumen antara lain efek samping yang ditimbulkan, tidak adanya takaran penggunaan, kemasan kurang praktis, dan harga terlalu tinggi. Setelah dilakukan uji penerimaan produk, fitur-fitur yang ditawarkan pada produk dapat mengatasi permasalahan-permasalahan konsumen. Produk dapat diterima oleh responden, sebanyak $87 \%$ responden mengatakan akan membeli produk yang ditawarkan. Harga yang diinginkan sebesar Rp 20.000 per botol ukuran $30 \mathrm{~mL}$. Berdasarkan analisis finansial, industri obat kumur konsentrat layak untuk dijalankan. Total biaya investasi yang dibutuhkan sebesar Rp 1.240.250.000 dengan harga pokok produksi sebesar Rp 6.808 per botol ukuran $30 \mathrm{~mL}$. Nilai Net Present Value sebesar Rp 3.598.995.423; Rasio B/C 2,97; IRR 136,8\%; dan Pay Back Period selama 1 tahun 10 bulan.

\section{Saran}

Perlu dilakukan penelitian lanjutan untuk menentukan umur simpan produk, memperbaiki prototipe produk agar dihasilkan produk yang mudah digunakan, serta melakukan uji klinis produk.

\section{DAFTAR PUSTAKA}

Andayani ANA. 2007. Studi perilaku konsumen obat kumur listerine di Jakarta. [Tesis]. Bogor (ID): Institut Pertanian Bogor.

Blank S dan Dorf B. 2012. The Startup Owner's Manual: The Step-by-Step Guide for Building a Great Company. California (US): K\&S Ranch, Inc. Publisher.

[BPS] Badan Pusat Statistik. 2013. Proyeksi Penduduk Indonesia, 2010-2035. Jakarta (ID): BPS.

[BPS] Badan Pusat Statistik. 2017. Perkembangan Indesk Harga Konsumen/Inflasi. Berita Resmi Statistik No. 80/09/Th. XX, 04 September 2017

[Internet]. Diakses: 2019 September 8. Tersedia pada: https://www.bps.go.id/pressrelease/2017/09/0 4/1292/agustus-2017-deflasi-0-07persen.html

Farris PW, Bendle NT, Pfeifer PE, Reibstein DJ. 2010. Marketing Metrics: The Definitive 
Guide to Measuring Marketing Performance. Ed ke-2. New Jersey (USA): FT Press.

Harman DTA. 2013. Efektivitas antibakteri ekstrak daun sirih (Piper betle Linn) terhadap bakteri Enterococcus faecalis (penelitian in vitro). [Skripsi]. Makassar (ID): Universitas Hasanuddin.

Kamaludin A. 2016. Ketimpangan Turun, Ekonomi Masih Dikuasai 20 Persen Penduduk. [Internet]. [diunduh pada 2017 Agustus 12]. Tersedia pada: http://katadata.co.id/berita/2016/04/18/ketimp angan-turun-ekonomi-masih-dikuasai-20persen-penduduk

Karimi M. 2019. Advantages of alcohol-free mouthwash for children. Cientific Dental Research Journal 1.2 (2019): 01.

[Kemendag] Kementrian Perdagangan Republik Indonesia. 2014. Warta Ekspor: Menyibak potensi pasar obat herbal tradisional. Edisi September 2014. Jakarta (ID): Kemendag.

Klimchuk MR, Krasovec SA. Desain Kemasan: Perencanaan Merk Produk yang Berhasil Mulai dari Konsep sampai Penjualan. Jakarta (ID): Erlangga.

Kotler P dan Keller KL. 2008. Manajemen Pemasaran Jilid 2. Jakarta(ID): Erlangga.

Kulkarni P, Dhirendra KS, Mohamed J, Arnab M. 2017. Comparative Evaluation of Antiplaque Efficacy between Essential Oils with Alcohol-Based and Chlorhexidine with Nonalcohol-Based Mouthrinses. Journal International Society Prev Community Dent.; 7(Suppl 1): S36-S41. doi: 10.4103/jispcd.JISPCD_131_17

Kumar P dan Athiban R. 2017. Effects of alcohol containing mouthwash on oral tissue: a review. International Journal of Science and Research. 6 (6).

Lemos-Junior CA dan Villoria GEM. 2008. Reviewed evidence about the safety of the daily use of alcohol-based mouthrinses. Brazilian Oral Research. 2008 22(1): 24-30. Doi: $10.1590 /$ S1806-83242008000500005
Marchetti E, Stefano M, Jonathan DM, Fabio C, Salvatore DM, Antonella M, and Giuseppe M, 2011. Efficacy of essential oil mouthwash with and without alcohol: a 3-Day plaque accumulation model. Trials. doi: 10.1186/1745-6215-12-262

McCabe WL, Smith JC, dan Harriot P. 1985. Operasi Teknik Kimia Jilid 1. Ed ke-4. Jakarta (ID): Erlangga.

McCabe WL, Smith JC, dan Harriot P. 2005. Unit Operation of Chemical Engineering. Ed ke-7. New York (US): McGraw-Hill Education.

McCullough MJ, Farah CS. 2008. The role of alcohol in oral carcinogenesis with particular reference to alcohol-containing mouthwashes. Australian Dental Journal. 53: 302-305. Doi: 10.1111/j.1834-7819.2008.00070.x.

Montaño JMC, Julio JJA, Emilio GM, Estefanía BM, Miguel LL. 2018. Alcohol-containing Mouthwashes and Oral Cancer: A Mechanistic Explanation. Preprints (www.preprints.org): doi:10.20944/preprints201803.0044.v1

Moraes PIC, Neves LE, Souza CK, Parolia A, Barbosa SA. 2014. Comparative Effect of Mouthwashes with Different Alcohol Concentrations on Surface Hardness, Sorption and Solubility of Composite Resins. http://www.oralhealth.ro/volumes/2014/volu me-2

Moreira AD, Mattos CT, Araujo MV, Ruellas AC, Sant'Anna EF. 2013. Chromatic analysis of teeth exposed to different mouthrinses. Journal of Dentistry. 41(s): 24-27. Doi: http://dx.doi.org/10.1016/j.jdent.2012.12.002

Moss DR dan Basic M. 2013. Pressure Vessel Design Manual. Ed ke-4. Oxford (UK): Elsevier 